Palazzolo. "We've got to talk about this now, nail down some talking points for Bob."

Mr. Palazzolo is the office's point man for patent reform and some other issues. His specialty is the budget. His expertise on such a visible issue might have garnered him a more prestigious assignment with a seasoned lawmaker or a prominent committee, but he chose to work with Mr. Ehrlich, a second-term Congressman just assigned to the House Budget Committee, because he knew he would be needed.

The dozens of faculty fellows on Capital Hill benefit from their experience, and the lawmakers profit too. Having a fellow is a sign of prestige, says Mr. Kreseki. It also means having another staff member, at no cost. In Mr. Palazzolo's case, the university pays half his salary, and the American Political Science Association pays the other half.

His days are spent doing research on issues, writing position papers, attending hearings, and talking with constituents and lobbyists-work he believes will enhance his teaching about the legislative process. "I'll ask students to think a little differently about policy analysis," he says. "I'll talk more about staff, about money."

Today, however, patent reform rules.

At 11:45, an inventor from Mr. Ehrlich's district shows up, agitated about the patent bill. For half an hour, Mr. Palazzolo tries-but fails-to win him over.

Still, the professor respects the man's grasp of the issues. Informed critics are the exception, he says. "The level of analysis, from other members, from lobbyists, and from constituents, is often superficial.

"As soon as somebody makes a policy statement, everybody and their brother faxes you their opinion, without having given the policy statement much thought. I'm thinking: 'God, has anyone stopped to give this issue any real thought?'”

Reprinted with permission from The Chronicle of Higher Education

\title{
Educational Testing Service Drops Political Science Exam
}

Due to a steady decline in the volume of examinees, the Educational Testing Service will discontinue offering its Revised Political Science Test for postgraduates. The low volume of examinees, ETS announced, brought into question the statistical validity of examination results. As a result, the exam will be offered for the last time in December 1997. ETS also announced the December 1997 discontinuation of the Revised Education Test, citing a similar low volume of examinees. 